\title{
A New Paradigm of Character Education During Covid-19 Pandemic: Comparative Analysis Towards Digital Revolution
}

\author{
Anita Trisiana ${ }^{1}$ \\ ${ }^{1}$ Civic Education, Faculty of Teacher Training, Slamet Riyadi University Surakarta, Indonesia \\ *Corresponding author. Email: anita.trisiana@gmail.com
}

\begin{abstract}
During this pandemic, new educational paradigms emerged to innovate to create creativity. They have to adapt more in using technology, and realize the important role of digital technology in supporting learning. The strategy of strengthening character education becomes a new challenge. The purpose of the discussion in this article is to analyze the new paradigm of character education during a pandemic, as part of a comparative analysis towards the digital revolution. The method used in this research is descriptive research, which is to find answers fundamentally about cause and effect, by analyzing the factors that cause the occurrence or emergence of a particular phenomenon or event. The results showed that: Education policy strategy during the pandemic, experienced a shift. One of them is the application of character education. The policy of strengthening character education which has been contained in habituation is taught, accustomed, consistently trained, becomes a habit, becomes a character, becomes a culture in the environment that can be applied starting from home, class, school, and society. Digitalization needs to be aligned with the character value that can be created when learning at home such as; the value of independence, mutual cooperation, and creativity. Character digitalization is carried out by: First, utilizing the internet, applications, or digital content itself as a source of character education. Second, through supervision and assistance by parents or educators to students in utilizing digital technology.
\end{abstract}

\section{Keywords: Character Education, Pandemic, Digital Revolution}

\section{INTRODUCTION}

Implementation of the Education in Emergencies Coronavirus Disease (Covid-19) by Circular No. 4 of 2020, then study from home, the Education Minister stressed that learning in the network (online) / control implemented to provide meaningful learning experiences for students, without burdened with demands to complete all curriculum achievements for class promotion and graduation. The Ministry of Education and Culture recommends for the regions that are already learning from home ensure especially for the teachers also teach from home to maintain teacher's safety. The Minister of Education and Culture in the contents of Circular Number 4 of 2020 also stated that online / distance learning is focused on increasing students' understanding of the corona virus and the Covid-19 outbreak. The learning activities and assignments can vary between students, according to their respective interests and conditions, including in terms of gaps in access / learning facilities at home.

Previously, there were a lot of schools that used technology in learning, then in this unusual condition, all schools in Indonesia were forced to apply technology in the teaching and learning process. In fact, technology cannot fully help the learning process from a distance become easier to implement. There are many obstacles faced by students in using technology in the distance learning process, especially for students and teachers who live in remote areas, those who live in remote areas, plus economic conditions that do not allow parents of students to have an e-smartphone and must buy internet quota to access the internet every day. Putting aside the above limitations, this article wants to convey that there are obstacles that cannot be reached by technology more than that. Technology cannot touch one of the essence of education, namely character education. Literally, [1] character is quality of mental or moral, moral strength, name or reputation which is 
limitations, [2] "Character is a personality viewed from an ethical or moral point of departure, for example a person's honesty; usually have connections with the properties of a relatively fixed. In contrast Hornby and Parnwell and [3] Gulo, Kertajaya stated that character is the hallmark of which is owned by an individual or object. These characteristics are genuine and rooted in the personality of the object or individual and are the engine that drives how a person acts, acts, speaks and responds to something. Based on these three opinions, [4] Hidayatullah stated that Character is the quality or mental or moral strength, character or character of an individual which is a special personality that is the driving force as well as what distinguishes the individual.

Character can be formed and developed through educational efforts. This studies in terms of education are termed character education. The discussion regarding character education is expressed by [5]. Character education as a result of human effort is not without problems. Character education becomes a kind of addition or accessory for humans in the form of a result of self- development. By humanities are created in a natural state or clean or good, but in the course of life, humans have experiences that make them good or bad.

Character is a relatively stable personal trait in the individual formed the basis for the appearance of behaviour within high standards of values and norms. The explanation about the character definition components can be explained as follows: Relatively stable; a condition that if it has been formed will not be easily changed. Base; Power has a very large / dominant and comprehensive influence on matters that are directly related to the power in question. Behavioural appearance; individual or group activities in fields and regions (settings) and spheres of life as mentioned above. Standard values / norms: the condition that refers to the rules of religion, science, technology, laws, customs, and habits, which is reflected in everyday life like: faith, devotion, self-control, discipline, work hard, and tenacious , responsible, honest, defending truth, propriety, decency, and politeness, obedience to regulations, loyal, democratic, togetherness, deliberation and mutual cooperation, tolerant, orderly, peaceful, and non-violent, frugal, consistent.

Good character is what we want our children to do. What are good characters consist of? A Greek philosopher named Aristotle defined good character as life by taking correct actions with respect to oneself and others. Aristoteles reminds us of what we tend to forget in the present time; life of goodness virtuous including self-oriented (like control and moderation) as well as the kindness oriented other things (such as generosity and compassion), and both types are related goodness. We need to control ourselves, our desires, and our desire to do good for others.

Character, according to the observation of a philosopher name Michael, is " a mixture of compatible of all goodness be identified by the tradition of religious, literary story, the wise, and collect the common sense is in history," as shown Novak, not there is nobody who has all of these goodness, and everyone has some weaknesses. People with a character who often dip test can be very different from one another.

Character education is emerging as an evaluation of the education that rests on the western point think of modernism which positivism is making the human soul dry due to industrialization friction values spiritual and humanitarian. Positivism split between subject and object in a dichotomous seen as the cause of the loss the world meaning in human beings when modernism was the idea o logy impressed confirms human activity to click the exploitation of nature. The ideal of freedom is actually separated from the meaning of human subjectivity because it is accustomed to make the people believe only in crude things and something that usually verified.

The mistakes of modernism which consider education include the influence of positivism that views education as a means of conquering nature where humans must submit to natural laws which are considered evolutionary. Here education loses its values, namely the subjective human beings who should be respected, lose their meaning and are reduced to only quantities of material achievement. Furthermore, from the other side there is criticism that modern education has lost its transcendental and spiritual dimensions. It is the party that puts more emphasis on character education that re-echoes the spirit of religion.

However, what needs to be remembered, character education is also not only religious education and moral education. Character education has variants interpretation of the humans. We will look at different points of pressure in the appropriate time trajectory, how character education is interpreted. Therefore, it is better if we look at character education in the dynamics of history and different regional trajectories (places).

Character education is the whole dynamics of interpersonal relationships with various dimensions, both from within and from outside, so that the individual can increasingly live out his freedom. Based on that, he can be more responsible for his own growth as a person and the development of others in their lives. Character education is understanding first relational dynamics experienced by individuals in and with the environment, the main assessor of character education is the individual itself.

Since, character education is unique to the individual. Character education needs to pay attention to the potential that the individual has or be based 
on self - potential. According to Khan (2010: 14), "Education based self- potential (people) is an education that not only guide and nurture all students to have the intellectual competence, mechanical skills, productive, innovative, and character development ". Character education based on one's potential. The desired goal is a change in attitude from

being counterproductive to creative and counterprodu ctive.

In the history of human civilization, education character get his voice echoes still sounds up to now since in echoing by Civilization Yunani Ancient par a philosopher. The reason of that studies because civilization is the place where the ideals of humanism emerge, the place where the thoughts that became the origin of human values until now have developed.

Through various street historically Education characters over time, Objective discussion in this article is analyse the new paradigm education character of future pandemic, as part of a comparative analysis to the digital revolution.

\section{METHOD}

Qualitative descriptive research is one of the types of studies included in qualitative research. The purpose of this research is to reveal events or facts, circumstances, phenomena, variables and circumstances that occurred during the research by presenting what actually happened. According to [6] the descriptive method is a method of examining the status of a group people, an object, a set of conditions, a system of thought or a class of events in the present. The purpose of this descriptive study is to make descriptions, pictures, or paintings systematically, factually and accurately regarding to the facts, characteristics and relationships between the phenomena being investigated. [7] Descriptive method is a method used to describe or analyse a research result but is not used to make broader conclusions. According to [8] Whitney, descriptive method is fact finding with correct interpretation.

The problems that can be researched and investigated by qualitative descriptive research refer to quantitative studies, comparative studies (comparisons), and also can be a correlational study (relationship) between one element and another. This research activity includes data collection, data analysis, data interpretation, and conclusion that refers to the data analysis. The purpose of qualitative descriptive research is in line with the problem formulation and research questions or research problem identification. The purpose of this research is to answer the questions previously raised by the problem formulation as well as research questions / problem identification.

\section{RESULT AND DISCUSSION}

\section{1) Ancient Greek Character Education}

One of the witnesses to the emergence of ancient Greek ideas can be seen from the works of Homer. His works are about the vision of character education. His well-known work includes poetry in "Illiad" and Odisea ".

Homeros puts history as the story of heroes. The heroes referred to are big people with good character. Such a great person means a good human being (aner agathos). His charm is the character of the aristocratic (aristocrat). The characteristics are the people who have arete, which refers to physical strength, which gives rise to the character of courage, which makes the identity honorable and successful without flaw. It also means strength, tenacity, prosperity, intelligence, wholeheartedness, health, wisdom, joy, and other advantages. In his epic work, "Illiad ", Homeros has a hero who wins in battle. Not only physical strength, but also because of a reputation worthy of being the character of the next generation.

Apart from Homer, other Greek poets also presented the virtues of the army (Tirteo and Callino), the virtues of sports (Pindaro), the values of citizens (Solomon), as well, the virtues of being eloquent and oratory (for example, the sophists. and Isocrates). To, also appeared virtue of philosophy as we see in Plato.

The virtue of values taught by Hesiodos, whose moral basis is justice and hard work. This is an interesting thing. He considered that whoever worked he was doing justice. Character teachings like this were even aimed at the judges, as if he were a prophet of justice.

Hesiod believe that work is a virtue, which confirms that the concept of arate ever thrown Homer not only belong to the nobility or the rich alone. It can be owned by many and the common people, the working class. Those who do not work, according to Hesiodos, behave unfairly and find it difficult to see justice.

So, Hesiods has shifted aristocratic values (the rich) of Homeric become more populist based on the primacy of the majority. It is the respect for the value of work that later in modern times will give rise to a new philosophy which wants to affirm that philosophy and human values are based on universal interests. It also based on the working class. Philosophy is Marxism which emerged since the 19th century.

It turns out that moral values existed in Ancient Greece. In Greece, there have been many philosophers with different emphases, although they end up with the values of humanism and democracy. Homer and Hesiodos are the names of 
historians and poets who were able to capture emerging values.

There are other names, like Tirteo, which reveal the appearance of virtue there is in people who are very nationalism who like to fight for his country. He referred to Sparta as a nation with such virtues. This is a new spirit for citizens. Sparta taught how patriotism is a very important value, a place where people must dedicate themselves to their country and must be followed by culture to sacrifice and eliminate individual interests.

It is different from the city state called Athena. Sparta had a patriotic and warlike character with courage. Athens was synonymous with democratic values and was filled with many philosophical and beautiful thoughts. Athens was once a witness to brave warriors, but then underwent a significant shift towards a city-state that coloured by efforts to seek policy. The character of the military disappeared into civil society which gave birth to values that would later become the forerunners of human knowledge. The progress of civil society occurred since Athens was pioneered by Solon $(630-560 \mathrm{BC}) . \mathrm{He}$ is a reformer who is very passionate about arts and culture. His position as anarconte (a kind of legislative member in Greece who has the authority to run the government) was very historical when he started a consensus with the members of the polis. It is the responsibility and right is not only the nobles, but also of all citizens.

Civil life was increasingly developing during the kingdom era in Athens in the time of Pericles (about the 5th century BC). Education started to become activities useful in order to educate civic virtues. Civil education is based on the dissemination of democratic values and individual rights, where the art of conveying ideas is very well known, especially the art of speaking through rhetoric and oration. The values carried by the Sophists are very important in their meaning that the aims to create a democratic political character. People became interested in the search for wisdom and the expression of ideas carried out in beautiful and interesting words.

The people are negatively label as a people who only like to fight their tongues. They are thought to spend a lot of time on the art of speaking, but care less about the truth. Here then begins to think about the importance of the values of truth and the essence of a thought. This is what then gave rise to Socrates (470-399 BC) who invited him to return to the human soul and not to the beautiful speech techniques. The well-known yes statement is "Know yourself", not just a name, but as the essence of the soul that distinguishes us from other lowly beings.
His contribution in philosophy and the path in order to wisdom rests on the human need to come to know the world through knowledge. The method he introduced was the inductive reality testing method. So crates attempts to devote his attention to the development of methodologies or procedural models to reach the truth until he finds a method of definition or dialectics in terms of critical testing of the truth of an opinion.

Through a continuous question and answer process, he tries to penetrate the essence or essence of the subject, such as justice or freedom, to arrive at a universal definition. First of all, he looks for the superficial definition of the term and his listeners and then, through cross-examination, invites them to look at its flaws. The questions always led them gradually and felt to the territory which he believed was the place of truth. Each step is directed at a critical inspection of the mind. Socrates calls this method the maieutic (from the Greek maieutikos which means midwife). Nonetheless, it is the intellectual art of midwifery that tries to remove the written thoughts from the thinker and directs them to reach the essence. The Socratic Method is well described in Plato's dialogues, his which is also a more real political philosophy than Socrates.

For Socrates, the formulation of the doctrine of goodness is knowledge. According to him, a wise person is a person who knows while a sinner is a fool. Correct knowledge will lead to right action. Evil actions are the result of poor insight. It was inconceivable for him that someone who knew the basis of goodness and truth would do evil. Since no human being sins deliberately, knowledge is needed to make him truly wise. Therefore, it is obligatory to teach humans to understand and understand the greatness of the truth of life. By knowing the truth, humans will act wisely and will repair the damage to society.

The teaching that we can learn about Socrates' character is that the values are born from the correct knowledge that are very important for the formation of values held by a person. Without the correct knowledge of moral values, it will be difficult for people to do something moral. This is because moral actions are basic and free actions carried out for the sake of one's values.

After Socrates, came the name Plato (429347 BC) who was a student of Socrates. Socrates was executed by drinking poison. Plato is 29 years old. Plato is a real character educator, having founded a school of philosophy in a small forest not far from Athens, named after the legendary Greek hero, Academicus, This is the origin of the term academy, after which thousands of "academies" have sprung up in various parts of the world. At the academy, Plato taught for 40 years, only temporarily 
interrupted due to his going to Sicily several times. At the age of 81 , he died in Athens.

Plato's education character was touched by the pursuit of virtue in a time when education that only pursued success, respect, let alone popularity was considered a lowly character. Plato tries to print character with the measurement that a leader must be a wise person. He believes that a wise leader is a philosopher.

The warrior is to use the graciousness of his lust and courageous soul. This class includes the military and administrative officers, whose job is to protect the country and enforce the law. Producers associated with the five senses. They are a large part of the people whose job to provide material needs for society.

Why choose the main character is a man who has a right due to knowledge her? Because, wisdom is knowledge. In this case, there are three concepts that must be understood. First, truth must be objective and unchanging so that we can only attain knowledge of it. On the other hand, we can only have an opinion and not true knowledge. Second, since virtue is equated with knowledge, the person who knows must be given a decisive role in public affairs. The task of finding a good and wise ruler was thus carried out by means of a teaching test. Third, the state must take an active role in educating its people. Especially to those who believe in the guidance and direction of public life. A society that is getting wiser and functioning properly and is assisted by training to acquire broad capabilities.

Plato's education character departs from the belief that by printing wise people, we can create an ideal money country. The goal of the state in Plato's concept seems very ideal. Because the state is a common welfare. Plato said that "Our aim in upholding the state is not an imbalance of certain class happiness, but for the sake of happiness for all".

Plato's classical political thinking may be considered incompatible with modern politics today. However, there are some interesting things that have yet to be preserved. The main role that education for citizens has to play pressure that the state and political forces must do at this time, especially in Indonesia. His dislike of corruption and abuse of power, as well as the sweet dreams of the state's responsibility for the general welfare and society are still very relevant for the context of the state today.

The name Aristotle (384-322 BC) appears in place of Plato, his teacher at the Academy. Differences with his teacher Aristotle, Plato was very fun to eternal like "ideas", Aristotle actually very interested to note changes or what is called as a natural process. Aristoteles is very interested in paying attention to changes or what is called natural processes. Aristotle wanted to investigate the general properties of everything in this world. Prima philosophia, namely philosophy first and foremost, looking for the deep nature of what is. So, philosophy is the teaching of reality or anthology, a realistic way of thinking (as opposed to idealistic philosophy).

One of the famous works written by Aristotle, namely Ethics Nikomakea. In this book. He said that life should aim at eudamania which when understood will result in good and wise actions and morals. In fact, it is a compilation of writings that were originally notes from his lectures at the Lyceum which were later recorded as an offering to his son Nicomacus.

Aristotle's ethics is known as ethics that are teleological, goal-directed ethics. Aristotle thought that everything has a purpose and a purpose. For example: a knife is made for the purpose of slicing, cutting, and so on. Living humans also have a purpose. Human a right thing with the goals that of skills, actions and achievements knowledge also has a goal, such as creating drugs for health, create to help facilitate life science, and others. In short [9] "human nature in general and moral goodness in particular depends on the idea of the basic goal of man". From this opinion, moral education is based on dispositions that require practical training in line with moral authority itself.

In interpreting education, he finally emphasized the practical goals of education. This practical goal is a daily policy that deals closely with ethical and political dimensions. Attitude to ethics is called "Ethics Policy" or ethics: actions everyone should make them better and build better character anyway. Others will see us as brave people (thus assuming Aristotle) if we generally take bold actions when the opportunity arises. The Nikomakean ethics are considered as an example of such policy ethics. We agree with Aristotle that intellectual policy is a value that must be upheld. Aristotle outlines five to intellectuals, among them: knowledge of art, prudence, and wisdom.

After Aristotle, it turned out that there was a historical reversal that would begin to end Greece's glory. After Iskandar's death in 232 BC, the world was divided. Thus, in a country emerging Yunani city like Aetolia and Archaia, which is an independent government that union. This situation continued until Greece later became part of the Roman Empire.

The transition era marked the push for Greek universalism that has been upheld since Socrates, Plato, and Aristotle. Around 300 BC, a shop named Epirus (341-270) appeared, a man who 
had been a student of Socrates. Epicurus 'views were heavily influenced by Artippus' enjoyment ethic, which believed that the goal of life was the highest possible sensual pleasure. The highest good is enjoyment. The highest evil is suffering. Of course it's not just physical enjoyment but falls into that category. Values such as friendship and respect for art are also included.

This view seems to be the anti-thesis of the tendency of Ancient Greece that full of the teaching that is life requires self-control, simplicity, and sincerity, lust must be restrained and peace of mind will help us endure suffering. The tendency of the Epicurean philosophy (Epicurus) can be said to be materialistic, which teaches that the good human character is emphasized on seeking material pleasure. He assumed that the soul was nothing more than a touch, like particles of breath and blood pressure scattered throughout the body.

Epicurus denied that there were intrinsic virtues and moral values or objective standards for truth and error. Men serial actions that because the crime negligence caused such actions make them feel uncomfortable or cause pain. The philosophy of materialism which he held made her think that if happiness consists of freedom from concern, the personal moral responsibility and the fear of consciousness and a game cannot get wrought $t$ in life.

Previously, Plato tried to improve the tendency of the hearts of people in the country by means of dialectics. Aristoteles shall maintain and want to fix it with the knowledge of the actual reality, Epicurus is precisely the attitude of thought indifferent as forced, which provides adjustment of mind and late to the circumstances of the dilapidated, without hope, and without trying to save oneself from them. Because of this kind of thinking, Epicurus described the state and law as only a moment which turned out to be of no value at all for a later date. That is, the character he builds is based on pessimism on moral and ethical standards.

2) Roman and Medieval Character Education.

The coming of the Roman era must be seen from the continuity of previous history. When Yunani's influence did not disappear completely. In the history of political thought. Rome can be said to carry an idea that was a transition from the Ancient Greek era to Western European thought of the Modern Era. The Romas is known not for its political theory, but for its law, and in a sense also for its administration. In this area that the Romans left in the West. Character education in the Roman era was largely shaped through the family. Character education emphasizes the values that are socialized through the family. Values that contain elements of tradition passed down by the ancestors. Character elements that stand out from the Romans are values such as prioritizing the goodness of the homeland, devotion (la pietas) or the worship and reverence of the gods, loyalty (la fides), quality behaviour (la gravitas), and values, value of stability (la constantia).

In the next era, we will see how character education is strongly influenced by Christian teachings and the emergence of this religion, which marks the age of religion which is sometimes referred to as the Dark Age before the emergence of the Indus tri revolution and the age of enlightenment. The era of darkness" occurred when education and its direction were hegemony by the church.

Character education in this era synonymous with religious moral education which does offer moral concepts and values are seen as the answer to moral problems before. One of them is the decay of Roman power, both morally and politically. Despite its legitimacy and strong juridical (legal) basis, the Roman Empire had fallen into a state of disrepair and weakness. Regional (Provincial) Government becomes Demoral and only thinks of its own interests and is very corrupt. In the Roman cities there were also the poor and hobo who caused all kinds of riots and resistance. In the realm of ownership, the beginning of the AD century was marked by a hopeless situation. The emperors became increasingly despotic and corrupt. In that situation. Christian teaching had a tremendous impact. The birth of Jesus and his understated manhood hypnotized the Romans. The followers of Jesus of Nazareth grew more and more followers, bringing a new religion to the people, also spreading a new awareness, new understanding, and a new hope of forgiveness. Christianity is quickly enter. The latter also gained acceptance in the political environment of the state, until the church controlled the state.

Education for children is directed at a religious character in accordance with Christian teachings. The ideal of Christian education is the personal drive to be able to respond to an offer of free love of God who has redeemed their sins them, with the help and grace to holiness, to be a saint and the saint.

In fact, Christian character education was processed based on the desire for the power of the aristocrats who took refuge in the church and this resulted in various reactions. Among Christians, various movements began to question the position of power in the middle ages. There is a view that the relationship between man and God is more important than the relationship between man and the church. This means that symptoms began to 
emerge when the church's authority began to be questioned.

Significant protests in church history occurred on October 31, 1517, when an Augutinian pastor named Martin Luther posted 95 historical statements on the door of the Til Cash Church in Wittenberg. Martin Luther was dissatisfied with church hierarchy and church law, which he considered unscriptural and used only to acquire worldly wealth. The domination of the church and its dissatisfaction went hand in hand with the revival of love for the German nationality. Finally, he questioned the relationship between church and state. When the German emperor clashed with the kings, Luther first taught that Christians can defend themselves against arbitrary government if the emperor violates laws, for him the people do not have to obey them.

At the same time the morality of the church was getting pushed aside by the new ideas brought about by the Age of Enlightenment (Renaissance) as many people put it. This era occurred from the 14th to the 16th century. Of course, there is no development of thought that is not caused by the dynamics of material economy. When the church's legitimacy and dominance began to diminish, the church's interference in politics and state affairs began to be challenged. This is where the understanding of secularism appears, wants to separate religion from matters of state affairs / politics. People prefer knowledge and freedom of expression rather than a restrictive way of thinking, in the era of building magnificent cathedrals which became a symbol of God's glory, now directed towards the worship of humans. [10]; [11]; [12].

3) Modern Era Character Education

This is what makes a new era called "modernization" that was centered on humans (anthropocentrism). Subjective views are trying to get rid of because humans with the help of knowledge and rationality have been guided to see nature objectively because nature is an object that will be analysed and used to develop their life.

Ludwig Feuerbach in The Essence of Chritianity said that the religious is a dream, in which our views and emotions appear before us as an independent existence, which exists outside of us. Religious thinking does not distinguish which is subjective, which is objective. The thinker has no doubt; he had the blessing and not the ability to understand things outside himself, still in viewing themselves according to his own views as existence of special and privileged.

The dichotomy between the subject and the object is then considered as the cause of the emergence of various kinds of dryness of meaning in modern persons. Capitalist modernization with the various problems it causes (poverty and impoverishment, destruction of the natural environment, shallow culture, etc.) arises because human beings are considered separate from their subjective meaning in life. The busyness of life in pursuit of material progress and growth alone is thought to have created new problems in the realm of human character.

When talking about the impermanence of life and the destruction of human character in the modern era, there is a view which states that humans have lost their spirituality which can only be answered by religion. They offer character education that emphasizes religious moral education, which can be considered as solutions or problems of modernity.

However, there is also the view that it is not just a matter of religious meaning alone. Moral deterioration is not a problem of the human subjects, it should be understood as a part of the material life in general. In this case, the loss of subjectivity is not only caused from within himself, but by the conditions of the social environment which form the subject which even makes humans the object of exploitation as examples of the emergence of human problems. The destruction of human character and personality is not solely the responsibility of individual humans, but rather is more many are shaped by existing social conditions. Character education then overcome human problems is not enough to simply filling with the morality of religion, but also filled with awareness of the realities and enable human movement potential to address the reality that turns and degrade the character of his humanity.

The first viewpoint describes the importance of religious education which some people and groups must totally indoctrinate in order to organize humans and shape their character. Character building through religious education has been criticized for the potential for critical human reasoning because children are only given certain emotions which are sometimes incompatible with the necessary actions. In his essay entitled "Religion in Education".Bettrand Russell reveals some of the bad sides of religious education.

First, children are very intelligent, who found through thinking that arguments is uncertain. It would be broken spirit by the teachers that may be punished: and the children of other tendency to think alike, and may be prevented from reading books that can improve their knowledge and their reasoning.

Second, because today most people whose intelligence is far above the average agnostic (ignorant of religion) openly or secretly, teachers in schools who insist on religion are of course stupid and hypocritical, unless they 
are part of the class. Small ones for a tangle has the ability consideration. What happens in practice is that people who intend to accept the scholastic profession begin to close their minds to adventurous thoughts from an early age. They become timid and conventional in theory and then go through a natural transition in everything else. They become timid and conventional in theology and then go through a natural transition in everything else. Like a wolf that has lost its. They tell their students that it is good to be docile and conventional. [13]; [14].

Thirdly, it is impossible to in still a scientific zeal in young people as long as every proposition is sacred and not open to question. Is the core essence of the scientific attitude that is scientifically demanding proof of what you want to be trusted and that the scientific attitude follow it no matter the destination.

Betrand Russell's criticism was born to see what was happening in the West, a secular life and seemed to think strange things that were religious and mystical with science having different approaches to be strange. Science wants students who know and realize the reality of nature and are able to uncover social relations, especially for the advancement and peace of life according to human ideas measured in scientific terms. Meanwhile, religion and mysticism contain the view that life is regulated by something outside the human will. [15]; 16].

Character education in the concept of religion did not see the characters in children are the product of dialectics with their historical experiences and historical relationships with other people. Moreover, a religion that is interpreted rigidly will say that the measurement of good and bad is seen from the instant result, not as a product of social relations that produces power relations. Such religious existence only

knows "lawful" and "haram" based on the text which is interpreted in a sacred manner and is selected or interpreted according to certain interests. [17].

Finally, certain actions which may be controlled by a person's personality and character are judged without dialectic with concrete relationships that can be analysed based on material reality. So, there are only verdicts that sometimes kill a person's character in society.

Keep in mind that the assessment of character someone sometimes be a "character assassination" that makes people rated impacted psychology outstanding, parrots $g$ it if the poor judged by their poverty without as a product of society should (impoverishment due to the system). The goal religious moral education are the children of the poor to pursue $\mathrm{k}$ emphasis on teaching to be memorized, which is usually chosen according to the interests of power. Meanwhile, verses that can be interpreted to understand the situation of impoverishment are almost completely absent.

In the modern capitalist era characterized crisis $\mathrm{n}$ people, domination fatalistic character education contains the religious doctrines that make the generation of surrender has the effect of psychological. In globalization era, it was in a losing position in global relations, existing development character fatalism and traditionalism can be said in response to rapid social development and unable to face so that the feeling of the importance of traditional values bounce back. Tradition is used as a shield, raised, to seek "meaning" so that defeats in competing with education and science and technology and other countries get entertainment. [18]

One form of traditional education which originally contained religious teachings was Islamic boarding schools. This educational institution is now trying to position itself as an educational institution that equips itself with modern science so that Islamic boarding school students do not fall behind with capitalist modernization, even claiming to want to compete in the global arena. They are trying to reform and modernization of educational boarding institutions. [19].

Usually, the jargon that becomes the goal is to print a generation of faith and piety, but still not left behind in the competition in the modern era (globalization). The goal is to create the character of the generation who master science and technology and faith, master the science of technology and faith in piety. This is a natural expression as a dialectical law between traditional education and modern developments that are considered to destroy morals and humanity from the point of understanding religion. However, because the base is a boarding school, the remnants of its traditional character are still visible. For example, the pattern of relationships between students and teachers (or to be precise between students and cleric. Although teaching methods and equipment are becoming increasingly sophisticated, there are still some that are left behind; feudalism. [20]; [21].

Most of develop sophisticated education, contain complete equipment, commanded by teachers who have good and smart academic quality, with very advanced facilities. This traditional educational institution tries to adorn itself with progress, offering parents a training and education process that makes children's intelligence skyrocket and their level of intelligence will be much higher than that of ordinary schools. Some of the new schools that were built also tried to imitate the boarding school model, trying to modernize themselves with the 
aim that the school was visited by many children by selling the image of "boarding school" or education that taught a lot of religious morals. [22].

The average modern boarding school that adopts modern education also applies the full day school model to maximize the role of intelligence and mental formation in children. Most of them are managed to become commercial educational institutions so that many parents send their children to school by paying a considerable amount of educational fees. The author is tied to what Vernon Smith wrote. "The ideal parent for traditional education is one who keeps away from school, but sends money there as often as possible [23].

This education system has indeed tried to maintain the tradition of the boarding school model for a long time, where students must be fully in educational institutions right. These students are far from their parents. Parents who feel unable or lazy to educate their children at home or who are unable or lazy to educate their children at home or do not want to bother controlling the "moral" and "mental" of their children who go to school in " normal" ( general) schools, or those who fearing the impact of the non-religious education system which provides many moral and religious lessons for children, they would indeed prefer to spend a lot of money instead of carrying out their function as a guide and controller of their children at home and / or socializing outside the home and school. [24]; [25].

Based on various research and news state that in some religious educational institutions, such as boarding schools that are already adopting modern schools also appear education pitch trying to assert themselves to form a cadre - cadre who understand religion, even violently. Children are indoctrinated with strict and narrow religious interpretations so that they can be directed towards jihadist movements that justify violence and who are ready to go to war with the state often calling them terrorists [26]. The character building that is formed here is to build courage to fight (armed struggle) to realize the ideals of a religious state and consider that their own interpretation of religion is the most correct one, which is incompatible with them being considered " infidels " who deserve to be hostile.

For those of us who are open-minded and democratic, the building of a character which is trying to be directed at certain ideological political behaviour is of great concern. Children become victims of the doctrine of narrow religious beliefs which in fact benefit parents who want to do politics in religious clothes. It is no secret that the terrorist generation is the result of boarding school education, some of which are still very young, young, even children.

This is indeed a symptom of this present era, when capitalism raises welfare crisis that caused a crisis of existence of the self, character education in accordance with the interests of groups of people who stutter to correctly interpret life. The conditions mentioned above need to concern us all. Children and young adolescents who should have their rights to grow and develop into physically and spiritually healthy individuals must be saved from political turmoil and ideological conflicts.

What really matters is prevention. We have to prepare for a social condition that makes children victims. Victims are those who are marginalized. Maybe children will inherit the ideology of violence if they do not become part of the marginalized, persecuted, and even desperate. If we look at the children who are recruited into movements that use terror and violence, they are economically poor. Besides that, they are also deep because their parents and close relatives have also become victims. Behold, children who are raised in conflict areas, such as in the Gaza Strip, do not have any thoughts on how they can go to school and learn or play. Since childhood, they were taught to assemble bombs, hold weapons, and be trained to attack enemies. Because they have nothing else, their parents and their siblings have been killed by the bombs launched by Israel. [27] '

Still remember a few years ago, the Israeli attack on the Gaza Strip and other areas in Palestine had an enormous humanitarian impact. When the attack also preys on innocent children, who should have a peaceful and prosperous atmosphere for their development is something that is imagined. About 50 percent of the residents of the Gaza Strip are children of the dead. 220 of them are children under 17 years of age. Even children who survive will have problems. They were shocked, crying, for a reason they didn't know because someone was under five. The problems the children face will increase as their families are forced to flee to avoid the attack and part of their house has been razed to the ground. In fact, before the Israeli attack, around 50,000 Palestinian children were malnourished due to the Israeli blockade during the last 18 months on the Gaza Strip [28] [29]; [30].

Various pockets of violence and global war in some parts of the world have also drawn our children to engage in violent doctrine. The perspective of justifying violence has been injected into the minds and feelings of the children. The wars and imperialism have kept children away from the attention of their parents or loved ones. 
Such parental images of cruelty that teach children to hate and be hostile to other such groups are poisonous to children. However, children belongs to the world and they ha rus grow into a figure that has universal awareness about human relationships. We must prevent children from hating, but must be taught to love and to be involved in productive roles for the building of civilization.

First of all, what we must prevent is war and conflict, and the causes of that conflict we must understand and overcome together. We attack occupation and deprivation of rights, but we must also prevent reactions that have vengeful feelings for children. Set ach action depriving the rights of children and injure the child must be the kit a curse. The more important thing is we have to open our eyes from the point of view of one party which is full of doctrine to support narrow interests.

Such conditions should be avoided. The main way to return children to their true world is to provide them with prosperity, not to let them enter the battlefield with weapons and narrow ideological indoctrination. Also, don't let children plunge into the streets into beggars, vagabonds, thieves, and criminals. Bad children are born out of bad economic situations too.

We must save children, when humans are born, they are clean, holy and have great potential to develop into humans who will later be useful for civilization, useful humans are of course Productive, Creative, and Critical in facing the reality that is not only human imitate passive consumptive, and have a low awareness of the environment.

Because of that, children's character education in a macro sense is to create spaces of time that are conducive to children's development. We must prevent violence against children in a material-economic sense and at the same time an ideology in the form of internalizing the existing understanding and meaning of life. It is true that not only school who against child development, but also the family, and even as affirmed in our constitution states inability of the state and the economic system in providing the right material (nutrients, nutrition, housing and facilities life) and ideologically (through education) we must view it as violence against children and at the same time deny human rights.

4) Character Education in Indonesiaduring the Pandemic Period

In Indonesia, recently became a very hot issue since Character Education proclaimed by government Susilo Bambang Yudhoyono in National Education Day, May 2, 2010. A government's determination to shortly make the development of character and culture as part which is inseparable from the national education system must be seriously supported. However, we also still do not know how serious the government is in implementing national education policies to support the program.

Of course, the character of the nation can only be formed from the educational program or the learning process in the classroom. However, if education is serious about shaping the character of the nation's generation, there are many things that must be done, it requires awareness of educators and implementers of education policies. [31].

If education is understood in a broad sense, as a process of awareness, intelligence, and mental and character development, of course it is only synonymous with school, however, it is related to the generally ongoing cultural process, which has the ability to direct awareness, supply information, help perspective, and build the character of the young generation in particular. That is, the character that concerns the perspective and habits of students, adolescents, and young people in general is only very little formed in classrooms or schools, but more is shaped by social processes which are also inseparable from the process of ideological formation of economic material orders. It is running.

So, it is indisputable if the character of the nation, especially its youth, is formed through a historical process that materializes awareness, character, point of view, and mentality through existing media, socio-cultural institutions, and even has a very political character because it forces interests. A power shapes the character. [32].

Efforts to trace character education in the history of Indonesia seem to have difficulties faced with the fact that our country consists of various social groups that try to impose the concept of character building through state power. Not to mention the many nuances of ethnicity, race, and religion. Problem large and religion that a lot of numbers. The problem with a large state that consists of many social groups is the difficulty of finding what character defines a nation and its state. There has never been a thickening of character in the body of this nation because there has never been a devastation at the stage of the old society, whose brief feudality has never been a revolution. As a colonized country, the characters that are formed also experience dwarfism. However, at least, history has shown that there are efforts to build a strong character (character building) to complete the national development process (character nation building).

Changes that occur in view of the character education can be analysed with the theory of transformation, Etzioni writing in a book set titled anthology "Social Change". The 
theory of transformation in his article in the untitled "Toward a Theory of Societal Guidance. Etzioni related this theory to the typology of society. Broadly speaking, he divided the typology of society into two, namely passive society and active society. He explained the characteristics of the two types of society. $\mathrm{He}$ uses two dimensions which are the main characters of society. The two dimensions are control and consensus. There are societies with high levels of control and consensus; there are societies where control and consensus is low. Societies whose control and consensus reach a high level of control enter into active society; and if the control and consensus is low it is a passive society.

Character education in past pandemics when learners were school from home (school house) can remain guarded and controlled by teachers. One of them is by providing a character control sheet. There are many positive characters that can be developed by teachers according to the core competencies of the 2013 curriculum such as having religious, honest, disciplined, responsibility, caring, tolerance, mutual cooperation, polite, self-confidence, etc. Teachers can develop control sheets to give to students and for parents. The control sheet is assessed by the teacher, after which the teacher provides feedback. The teacher then strengthens the characters that are already good and changes the characters that are still inappropriate. Teachers can also give awards (prizing) to students who excel at least by saying congratulations (congratulations) in the WA group of students, and giving punishment through personal WA (Whatsaap) channels so that their good name is maintained and the child does not feel humiliated in front of friends her friend. Students can also be congratulated if they work on assignments on time and are given punishment if they are late in doing assignments as a form of instilling a disciplined character. When there is news that a student is unable to do an assignment because he does not have an internet quota, the teacher can invite classmates to transfer credit as a form of empathy and caring character development. Teachers and homeroom teachers must always control every word written by students in the WA children group as a form of cultivating polite and characters in speaking and being responsible for all their words and actions.

Innovations that educators can do to implement character education in online learning begin with planning interesting lessons. This is in order to arouse the curiosity of students. Furthermore, in its implementation, educators can implement discipline by meeting online learning times or when submitting assignments. This study shows that the world is entering the 4th Industrial Revolution. This era was marked by sectors Technology Information that is the driving force all lines of human life. 4th Industrial Revolution is also characterized by three important things, y aitu Technology Information or digital technology, nano technology, and bio-technology. Indonesia must not be out of date. You can't miss this 4th Industrial Revolution. Everyone must be aware that we are now entering the 4th Industrial Revolution, and in line with the digital revolution that reaches all levels of society.

\section{CONCLUSION}

The new paradigm of Education characters future pandemic, total transformation in the education system, for it takes innovation, which supports digital revolution future pandemics, which can be done by:

a. Character-Based Digital Innovation, in the form of information technology integration in character education, to be realized in a structured and systematic manner and there must be a digital innovation clock in the form of online education to be an integral component of the hybrid education model in schools. Digital innovation does not always mean online learning, but also can be in the form of offline applications with various strategies for delivering material in the form of digital based content, especially for learning in areas that are not well covered by the internet.

b. Collaborative Innovation Policy is an effort to bring a new experience through collaboration between schools both independently similar per-school and perprovincial / district / city. The essence of this innovation is to bring together resources and strengths through collaboration and co-creation. This innovation is a smart step to create extraordinary values for the community, especially students, which would not be possible if each school were to run independently.

c. Digital Business Integration is in the form of unification of conventional business

processes that cannot be carried out again. Therefore, schools must move on, not being silent. Schools can innovate business processes in the form of online learning (online-schooling) using digital platforms. Second, the role of parents is getting bigger in the process of teaching children (home-schooling). In the future, if physical schools are no longer relevant, the online learning / online course platform equipped with licensed certification will boom. Parents are more able to control their children, to get character education used.

\section{ACKNOWLEDGMENT}

This research is part of the development of research results supported by the research project of the Ministry of Education and Culture on the Basic Research Grant, 2020 budget. Researchers also thank the Chancellor of Sla met 
Riyadi University who has helped the process of implementing this research.

\section{REFERENCES}

[1] Hornby, AS \& Parnwell, EC (1972). Learner's Dictionary. Kuala Lumpur: Oxford University Press.

[2] Kartini. K\& G ulo (1982). Psychology

Dictionary. Bandung. Pionir Jaya.

[3] Kevin. G. (2003). The ethics of zero tolerance. Journal of Educational Administration, 41 (1). (pp. 24-36). United Kingdom: MCB UP Limited.

[4] Furqon Hidayatullah, M. (2010). True Teacher: Build strong and intelligent character. Surakarta: Yuma Pustaka.

[5] Koesuma, Donie. (2007). Character Education Educational Strategy in the Global Age. Jakarta: Grasindo

[6] Narvaez, Bock, Lies (2004). The Community Voieces And Character Education (CVCE) Project. Journal of Research in Character Education, 2, (pp. 89-112). Bern, Switzerland: Peter Lang.

[7] Sugiyono (2010). Educational Research Methods: Quantitative, Qualitative, and R \& D Approaches. Printing - 10. Bandung: Alfabeta.

[8] Whitney (1960) Whitney, F. 1960. The Element of Research. New York: Prentice-Hall, Inc

[9] Larry P. N, Darcia Narvaez. (2014). Handbook of Moral Education and Character (Handbook of Moral and Character Education). Bandung: Nusa Media.

[10] Regards, B. (2000). Individual Ethics Basic Patterns of Moral Philosophy. Jakarta: Rineka Cipta

[11] Sarbaini. (2011). Learning Model Based on Moral Cognitive from Theory to Application. Yogyakarta: Aswaja Pressindo.

[12] Simon. (1972). Value s Clarification (A Handbook of Practical Strategies For Teachers and Students. Newyork: Hart Publish Company

[13] Stefa n, B . (2005). The Role of Environmental Ethics and Educational Approaches. Journal of Professional Issues in Engineering Education and Pract ice. ISSN 1052-3928. 3 (1). (pp. 114123). USA: American Society of Civil Engineers (ASCE).

[14] Lickona, T. (1987). Educating for Character: How Our School Can Teach Respect and Responsibility. New York: Simon \& Schuster, Inc.
[15] Lickona, T. (2004). Character Matters: How to Help Our Children Develop. New York: Simon \& Schuster, Inc.

[16] Lickona, T. (2003). Eleven Principles of Effective Character Education. Journal of Moral Education, 25 (1). pp. 93-100.

[17] Mayer, RE. (2008). Leraning and Instruction. New Jersey: Pearson.

[18] Mahoney. J \& and Other adults: Models

Hogan (2001), Parents and Monitors of Healty Media Habits. Handbook of Children and the Media, (pp. 7 26: 754). Thousand Oaks, CA: Sage.

[19] Spord, (2004). Philosophical Discussion in Moral Education (The Community of Ethical Inquiry). London: Routledge

[20] Tillman, D. (2001). Living Values Activities for Children 8 - 14. Jakarta: PT Grasindo

[21] Trisiana, A. (2015). The Development Strategy of Citizenship Education in Civic Education Using the Project Citizen Model in Indonesia. Journal of Psychological and Educational Research (JPER), 23 (2), pp. 111-124.

[22] Trisiana, Anita (2019). Innovation Design Development of Citizenship Education Models On Characters Of Indonesian Communities In Digital Media Era And Technology Revolution. International Journal of Recent Technology and Engineering (IJRTE). Volume 8 (2) September. pp 322-328.

[23] Trisiana, Anita (2020). Digital Literation Models for Character Education in Globalization Era . Humanities \& Social Sciences Reviews (HSSR), 8 (1). pp 522-531.

[24] Trisiana, A. et al. (2020). The Challenges Of Character Education: Mental Revolution Policy In The Development Of Citizenship Education In Higher Education . International Journal of Psychosocial Rehabilitation, 24 (8). pp 2340-2354.

[25] Wahyuni, S. T. (2012). Model of Fostering Character Education in the Boarding School Environment in Building the Independence and Discipline of Santri (A Study on the Development of Pancas ila and Citizenship Education). Indonesian Education Journal, 13 (2) . pp. 120-131. Bandung: UPI.

[26] Sutoyo, \& Trisiana, A. (2020). Innovation Of Development Of The Contextual And Value Clarification Technique (CVCT) In Learning Citizenship Education In Indonesia: Education. Humanities \& Social Sciences Reviews, 8 (2), 844 853. https://doi.org/10.18510/hssr.2020.8293 
[27] Sebestyén,V, Domokos, E., \& Abonyi, J. (2020). Focal points for sustainable development strategies - Text mining-based comparative analysis of voluntary national reviews. Journal of Environmental Management, 263, $110414 . \quad$ https: //doi.org/10.1016/j.jenvman.2020.110414

[28] Torres, E., \& Zeidan, R. (2016). The life-cycle of national development banks: The experience of Bra zil's BNDES. Quarterly Review of Economics and Finance, 62, 97-104. https://doi.org/10.1016/j.qref.2016.07.006

[29] Elwyn, G., Burstin, H., Barry, et al . (2018). A proposal for the development of national certification standards for patient decision aids in the US. Health Policy, 122 (7), 703-

706. https://doi.org/10.1016/j.healthpol.2018.04.010

[30] Grădinaru, SR, Fan, P., Iojă, et al. (2020). Impact of national policies on patterns of built-up develop ment: an assessment over three decades. Land Use Policy, 94 (May 2019),

104510. https: //doi.org/10.1016/j.landusepol.2020.104510

[31] Gubbels, S., Nielsen, KS, et al . (2016). The development and use of a new methodology to reconstruct courses of admission and ambulatory care based on the Danish National Patient Registry. International Journal of Medical Informatics, 95, 4959. https://doi.org/10.1016/j.ijmedinf.2016.08.003

[32] Kohlberg, L. (1973). The Calim to Moral Adequacy of a Higest Stage of Moral Jadgment". Journal of Philosophy, 70: 630-646. 